\title{
TEMPO
}

http://journals.cambridge.org/TEM

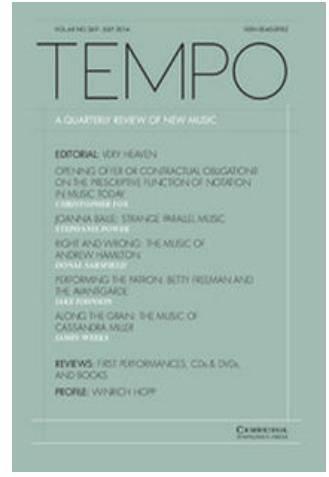

Additional services for TEMPO:

Email alerts: $\underline{\text { Click here }}$

Subscriptions: $\underline{\text { Click here }}$

Commercial reprints: $\underline{\text { Click here }}$

Terms of use : $\underline{\text { Click here }}$

\section{Henri Dutilleux and Maurice Ohana: Victims of an Exclusion} Zone?.

\author{
Caroline Rae
}

TEMPO / Volume 212 / Issue 212 / April 2000, pp 22 - 30

DOI: 10.1017/S0040298200007580, Published online: 23 November 2009

Link to this article: http://journals.cambridge.org/abstract S0040298200007580

How to cite this article:

Caroline Rae (2000). Henri Dutilleux and Maurice Ohana: Victims of an Exclusion Zone?. . TEMPO, 212, pp 22-30 doi:10.1017/S0040298200007580

Request Permissions : $\underline{\text { Click here }}$ 


\section{Caroline Rae}

\section{Henri Dutilleux and Maurice Ohana:Victims of an Exclusion Zone?}

Until recently, the music of Henri Dutilleux and Maurice Ohana was largely overlooked in Britain, despite both composers having achieved widespread recognition beyond our shores. In France they have ranked among the leading composers of their generation since at least the 1960 s and have received many of the highest official accolades. In Britain, the view of French music since 1945 has often been synonymous with the music of Olivier Messiaen and Pierre Boulez, to the virtual exclusion of others whose work has long been honoured not only in France and elsewhere in Europe but in the wider international arena. These 'others' include Dutilleux and Ohana. Developing an innovative and forward-looking approach, independent from the preoccupations of their contemporaries who congregated at Darmstadt, both Dutilleux and Ohana were excluded from representation at the concerts of the Domaine musical. As a result, their music was neglected in Britain throughout the years when the programming policies of Boulez and Sir William Glock were at their most influential. Undoubtedly, Boulez is one of the most phenomenal figures in music of the last 50 or so years and the position of his erstwhile teacher Messiaen is secure as one of the giants of the 20th century. Yet, however significant their respective contribution, Boulez and Messiaen represent only one facet of French music since 1945

Dutilleux and Ohana established their compositional presence during the years immediately following the end of the Second World War. Both had achieved a measure of success even prior to the outbreak of hostilities, albeit in slightly different musical fields.' As the crowning glory of his years at the Paris Conservatoire, Dutilleux was awarded the Prix de Rome in 1938, at his third attempt, for his cantata L'anneau $d u$ roi. He departed for Rome in February 1939, planning to remain in Italy for four years, but returned after only four months due to the tense political climate. ${ }^{2}$ During the 1930 s Ohana was

' Both composers settled in Paris in the early 1930s, Ohana in 1932 and Dutilleux in 1933. known more as a concert pianist than as a composer and by 1939 had given recitals at the Salles Gaveau and Chopin, performed concertos with the orchestras of the Concerts Lamoureux and Pasdeloup, and completed several European tours. (In 1947 he gave recitals in London at the Wigmore Hall as well as for the BBC Home Service.) Indicating the path of his subsequent compositional development, his recital programmes reflected a cultural alignment independent of the Austro-German tradition and typically comprised works by Scarlatti, Chopin, Debussy, Ravel and the Spaniards, Falla, Albeniz and Granados. During the same period he was drawn increasingly to composition and in 1937 enrolled at the Schola Cantorum where he studied with Daniel-Lesur. Ohana's first orchestral work, Les fêtes nocturnes, was performed in Paris the following year.

At the outbreak of war Dutilleux was mobilized. Although he expected his unit to be sent to North Africa, the French defeat resulted in his demobilization by the autumn of 1940 . Consequently Dutilleux spent most of the war years in Paris where, even despite the austerities of the Occupation, he was able to continue to work, compose and receive a few concert performances, including some broadcasts. Ohana's war years were very different and necessitated his absence from Paris. When he returned to Paris after demobilization in 1946 he was forced to carve out his position anew. Technically a British citizen (his father's family originated from Gibraltar), Ohana served with the British Army and saw active service in North Africa, Madagascar, Greece and Italy. Finding himself in liberated Rome in the summer of 1944, he took advantage of periods of military inactivity to enrol in Alfredo Casella's piano class at the Accademia Santa Cecilia. Beginning to compose again, his first important works Enterrar y callar,

\footnotetext{
"Henri Dutilleux: Mystère et mémoire des sons - entretiens avec Claude Glaymann (Paris, 1997) p. 42.

' The score is no longer extant. Ohana destroyed nearly all works composed before 1944 .

'Dutilleux, op.cit., p.43.
} 


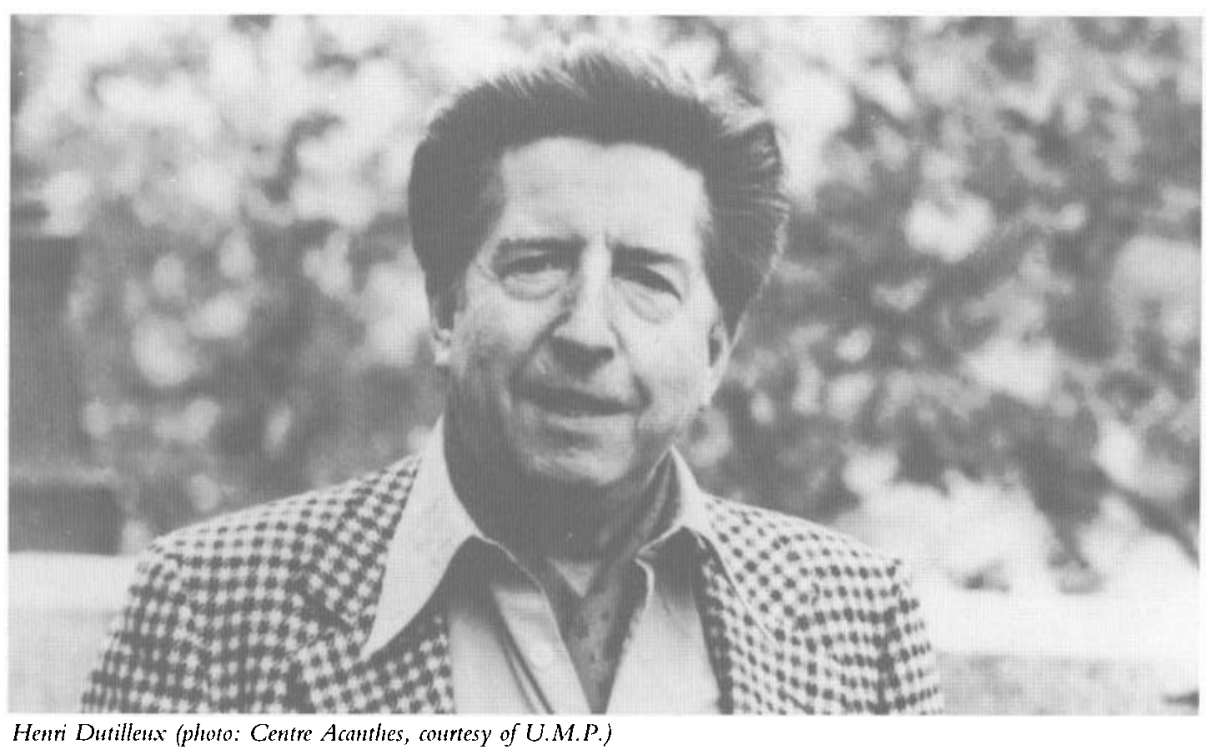

based on the eighteenth of Goya's etchings 'Disasters of War', and the Sonatine monodique, both for solo piano, date from this period. It was also at this time that Ohana became aquainted with André Gide who recorded their first meeting in his Journal on 17 December 1945. Ohana collaborated with Gide on the Notes sur Chopin (Paris, 1948).

By the end of the war, Dutilleux not onlyheld an appointment at French Radio (first Chef de Chant, then controller of Productions d'Illustrations Musicales) but had received several commissions, including from the Conservatoire for the well-known series of test pieces for wind instruments. He had completed works for the Orchestre Pasdeloup and the Société des Concerts du Conservatoire, in addition to a number of incidental music scores for radio, film and stage, as well as various songs. Although Dutilleux has frequently indicated his music of this period to be uncharacteristic of his later work, discouraging performances of any work pre-dating the Piano Sonata, his compositional preoccupations of the time reveal an instinctive attraction for modal colour, jazz-like harmonies, the use of recurrent pivot-notes and variation techniques. (Dutilleux has nevertheless allowed a number of his works predating the Piano Sonata to remain in public circulation.) As Dutilleux himself has said: 'Fundamentally, I am not an atonal composer'.' Clearly, he was not naturally drawn to the new serialism of the post-war years, considering it too dogmatic and authoritarian, yet it is possible that he may have experimented with

Roger Nichois: ‘Dutilleux at 75', BBC Radio 3, 1991. some primitive serial devices, perhaps as a means of confirming his compositional interests to lie elsewhere. That Dutilleux attended some of the lectures of Réné Leibowitz during the immediate post-war years may not be insignificant in this respect, although he has since emphasized that his interest was the result of natural curiosity, his position being quite different from that of Messiaen's students." (Dutilleux acknowledges just as much the importance of Milhaud and Jean Wièner in introducing Schoenberg to Parisian audiences.) In the third song of Trois sonnets de Jean Cassou ('Jai rêvé que je vous portais entre mes bras') which he composed during the late 1940s, the vocal line presents all 12 notes of the chromatic scale underlaid by the Alexandrine verse structure of the text." The melodic line barely disguises its tonal implications and the song as a whole is not serial. (Dutilleux employed a similar, although less primitive, device in the central movement of his orchestral work Métaboles and there are suggested quasi-serial sections in the Second Symphony.) Dutilleux has indicated that he might have been attracted by the compositional discipline of serialist technique as he always enjoyed the rigours of fugue and counterpoint, but could never accept the basic principle of abolishing all hierarchy between the different degrees of the chromatic scale."

\section{Dutilleux: op.cit., p.67-68.}

ibid.

"Caroline Potter: Henri Dutilleux his Life and Works (London, 1997) p.42.

Dutilleux: op.cit., p.47-48. 
When Ohana resettled in Paris after the war his reputation rested chiefly on his pianistic achievements; his compositional portfolio comprised less than a dozen pieces (many of which he later withdrew or destroyed). As a result of the opportunity for personal reassessment that his war service provided, Ohana decided to devote himself to composition and gradually wind-down his pianistic activities. With a musical language based on a combination of his Spanish and African roots and a reassessment of techniques drawn from the Medieval and Renaissance vocal repertoire, Ohana, like Dutilleux, was nor naturally drawn to the new serialism of his younger contemporaries; music stemming from the Austro-German tradition had long felt remote both culturally and aesthetically. In re-establishing his musical career Ohana received much practical help from his former teacher Daniel-Lesur who, like Dutilleux, held an important position at French Radio." Still, Ohana needed to find a means of both announcing his presence as a composer and confirming his independence from predominant compositional trends of his contemporaries. To this end Ohana was the motivating force in bringing together a group of like-minded composers who, in 1947, began to promote concerts of their music under the name Le Groupe musical le Zodiaque. Initially comprising only three composers, Ohana as representative and spokesman, Alain Bermat and Pierre-de-la-Forest-Divonne (all pupils of Daniel-Lesur, the latter also a former Messiaen pupil), they were joined in 1948 by Stanislaw Skrowaczewski, then studying with Nadia Boulanger, and the young Argentinian Sergio de Castro, a former pupil of Falla. (De Castro was hesitating between the vocations of composer, painter and poet and subsequently became known for his work as painter and writer. He was a life-long friend of Ohana and is also one of Dutilleux's admired contemporary painters, as well as a friend.)"

Unified as much by their diversity as by their similarity of purpose, the Zodiaque composers saw themselves as crusading knights defending freedom of musical expression from what they considered to be the tyranny of serialism. Their fierce repudiation of post-Webernian serialism was restated by Ohana some years later: 'Mere academic sterility, but as intimidating and terrifying as the propaganda systems of the Nazis...

Ohana and Daniel-Lesur also maintained a two-piano duo during this period.

"The covers for many of Ohana's $\mathrm{CD}$ recordings reproduce paintings of Sergio de Castro.
These systems destroy more in music than they create - they remove all the art of risk." ${ }^{\prime 2}$ The iconoclastic rejection not only of serialism but of all aesthetic dogma was primarily a rejection of Germanic musical thinking (not for the first time in France); while the political structure of the Third Reich had been defeated militarily, Ohana in particular feared that Austro-Germanic traditions were conquering culturally. Such a vigorous opposition to contemporary trends may also have been in part associated with the cultural origins of the Group Zodiaque members, their aversion to serialism being one of geography as well as of musical taste. While Skrowaczewski is Polish and thus has a tradition of kinship with France (not to mention a certain acrimony over then recent German actions in Poland), the remaining four members belonged to Latinate cultures. They considered the music of Latinate and Mediterranean countries to be under threat of annihilation by the all-conquering powers of Teutonic musical thinking. (It is interesting to note that a similar fear of Teutonic domination had also been expressed by the Spanish poet Federico Garcia Lorca.) $)^{13}$

Existing initially more as a compositional protest group, the Zodiaque composers were at pains to avoid creating their own dogma and only gradually developed more positive aims. They advocated an organic musical language that should emerge spontaneously from the material itself without recourse to elaborate pre-compositional systems, looked towards plainchant, much of the Medieval and Renaissance vocal repertories and set about a reassessment of their respective folkmusic traditions. They aimed, in so doing, to restore what they considered to represent a natural and true line of development from their most ancient, cultural roots. Many of these objectives may reflect the teaching of the Schola Cantorum which, from its beginnings, had promoted the study of folk music as well as the early contrapuntal masters. In the Cours de composition even D'Indy, renowned for his rigid academicism, had argued that musical form should be a consequence of musical material rather than a superimposed scheme. The ideals of the Zodiaque composers also have certain parallels with those of La jeune France, whose aesthetic was more than tinged with a certain nationalist resonance. Certainly the influence of Daniel-Lesur was

\footnotetext{
"Interview with Pierre Ancelin 1964: cited in Caroline Rae 'Maurice Ohana: iconoclast or individualist?' The Musical Times, February 1991, p.70.

"F. Garcia Lorca: Deep Song and Other Prose, tr. and ed. C. Maurer (London, 1980).
} 
more than spectral; he had been the teacher of three of the five Zodiaque group members, was immersed in plainchant and folk song and felt ill at ease with the serialism of the Second Viennese School.

The title of the Groupe Zodiaque, as esoteric in French as in English, refers to the division of the heavens into 12 equal parts, these including all the positions of the sun known to ancient man. (Presumably any implied, dodecaphonic allusion was intended to be ironic!) The four categories to which the 12 signs of the zodiac belong (earth, water, sun and air) correspond with the four compositionally active members of the group. (Sergio de Castro's commitments as a painter and writer placed him more as a sympathetic associate.) As the Zodiaque composers intended their compositional point of departure to stem from what they considered to be the primary elements of music - folk-song and plainchant - they chose a name which could suggest not only the primary forces of nature but the archetypal beliefs of ancient man.

The Groupe Zodiaque mounted seven chamber and orchestral concerts between October 1947 and March 1950, several of which were broadcast on French radio. A review in the Paris Spectacle of a concert in January 1948 records 'remarkable' performances of music by this 'interesting new group', citing a work of Ohana's for 'its dialogue of percussive effects'.' Their most important orchestral concert took place at the Salle Gaveau on 29 April 1949 and included works by Rameau and Roussel as well as by the Zodiaque members (with the exception of de Castro)." Conducted by Andre Girard, the event was well attended by the press (including the New York Herald) and enthusiastic reviews were received from Marcel Landowski, Maurice Imbert and Marc Pincherie. The inclusion of two works not composed by the members of the group once again suggests the spectral influence of both Daniel-Lesur and the Schola Cantorum. Not only had Roussel been Lesur's predecessor at Schola but he had also been a pupil of D'Indy, who was largely responsible for pioneering the Rameau revival in France. As Rameau had featured in concert programmes during the Occupation, it is possible that his inclusion in the Zodiaque programme may have been intended as a clarion-call to rekindle French nationalist pride in the face of

\section{+Newspaper cuttings from Ohana's personal archive.}

It is interesting to note that the inaugural concert of La Jeune France on 3 June 1936, also at the Salle Gaveau, also included a work composed by a non-group member: Germaine Tailleferre's Ballade for piano and orchestra.

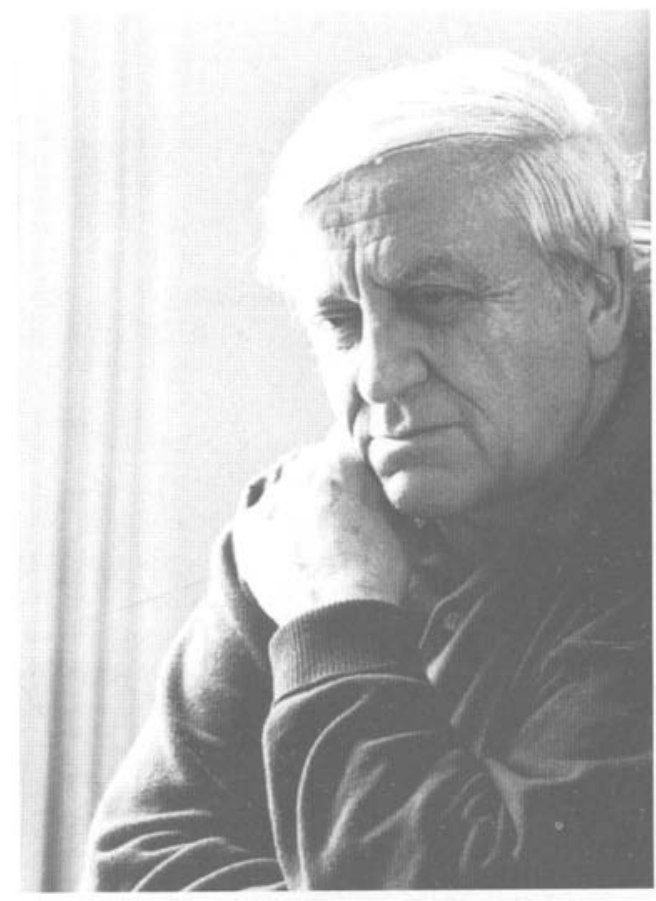

Maurice Ohana (photo: Gity Vivien)

Austro-German serialism. By 1950 the Groupe Zodiaque began to disintegrate; while Skrowaczeski, de Castro and Ohana succeeded in establishing themselves, Bermat and Forest-Divonne gradually abandoned their compositional careers.

The presence of Daniel-Lesur in a senior position on the music staff at French Radio almost certainly helped promote the music of the Zodiaque composers. The pluralist atmosphere prevalent at the time, especially at the recently liberated French radio where the influence of Henry Barraud, Pierre Capdeville, RolandManuel, Desormière and Rosenthal was keenly felt, resulted not only in the enthusiastic promotion of new music by the younger generation of French composers, but also a flood of broadcasts of music which had been suppressed under the Occupation. In addition to music by Schoenberg, Berg and Milhaud, this included music byStravinsky, Dukas, Prokoviev, Bartók and of course Mendelssohn." Keen to promote its newfound cultural and aesthetic freedom, the pluralist policies at the radio resulted in commissions from such diverse figures as Ohana, Prey, Nigg, Malec, Philippot, Delerue, Jarré, Petit, Constant," as well as Boulez, the latter for the first version of Soleil des eaux." (Désormière conducted both

Dutilleux: op.cit, p.48.

ibid. p.68.

Noted in Potter: 1997 p.188 and Jameux: 1991 p.257. 
Soleil des eaux and Le Visage nuptial.) Dutilleux was directly responsible for many of these commissions.

Dutilleux was sympathetic to the aims of the Zodiaque composers, although he did not wish to join them, inclined always to preserve his independence from any group or manifesto." The meeting of Dutilleux and Ohana was engineered by Daniel-Lesur who introduced them at his Paris home in 1948, feeling they would have much in common. A warm friendship was engendered and they remained in contact until Ohana's death in 1992. (Dutilleux attended Ohana's private cremation service at Père Lachaise cemetery.) Dutilleux commissioned several works from Ohana during his time at the radio and in 1962. Ohana's Tombeau de Claude Debussy, for soprano, zither, piano and orchestra (a French radio commission to commemorate the Debussy centenary), was dedicated to Dutilleux. The pianist Geneviève Joy, Dutilleux's wife, performed and recorded Ohana's early piano music and commissioned him to write a new piece, Sorôn-Ngo, for the twenty-fifth anniversary of her celebrated two-piano duo with Jacquéline Robin in 1970. The other composers commissioned were: Milhaud, Jolivet, Mihalovici, Auric, Daniel-Lesur, Petit, Constant, Louvier and, of course, Dutilleux." In his last published interview Ohana affirmed his admiration for the work of Dutilleux:

I saw the work of my friend Henri Dutilleux grow over the years and found within it a steadfast presence which encouraged me to pursue my own work with increasing exactitude... his music continues to send me signals, like two ships would exchange passing in the night, at the same time cnigmatic and comforting."

In 1993 Dutilleux contributed to a memorial publication about Ohana and wrote:

.... The unusual structure of his [Ohana's] music interested me from the time of his earliest works. In the 1950 s... our exchanges of ideas were fruitful, despite some minor differences of opinion... We shared a common admiration for music of the Medieval period, Gregorian chant and for the great harmonists and colourists Chopin, Debussy and a few others (the list was very short for him). His music, with its vital angularity and brilliant colours, bathed in light sometimes bright and dazzling, sometimes coolly moonlit, blossomed magnificently in his vocal and choral

"Dutilleux in conversation with the author in Paris, March 1998.

"Dutilleux: op.cit., p.54.

"Maurice Ohana: 'Anonyme XXe siècle' (entretien avec Jean Christophe Marti) Opéra d'aujourd'hui, Avant-Scène Opéra no. 3 (1991) [special Ohana edition] p.15. Translation by the present author. works and I am envious that he was able to adapt his personal style so well to the requirements of the human voice. I have in mind pages of his Office des Orades, Lys de Madrigaux and the startling discoveries of the final section of La Célestine.

Despite the relative success of the Zodiaque concerts and the exposure accorded the music of Ohana, it was the première in 1950 of his setting for baritone, female chorus, harpsichord and orchestra of Federico Garcia Lorca's monumental poem Llanto por Ignacio Sanchez Mejias which firmly established his compositional presence. In 1954 a commission from the Norddeutscher Rundfunk, which resulted in Cantigas for chorus and ensemble, made his music known in Germany. Since that time Ohana's music has been widely performed throughout western Europe and regularly available on commercial recordings. The success of Dutilleux's First Symphony following its broadcast première in 1951 (conducted by Désormière and the Orchestre de la RTF) and its championing by Charles Münch during the following years, undoubtedly led to the Koussevitsky Foundation commission of 1955 which resulted in the Second Symphony (premièred by Munch and the Boston Symphony Orchestra in 1959). ${ }^{2.3}$ The long association with the United States which ensued enabled Dutilleux to side-step any frustration that may have been developing as a result of Boulez's failure to commission him to write for the then newly-founded Concerts du Domaine musical. Ohana's music took longer to become known in the US; it only became more widely known, as in Britain, during the 1980s. He received his first and only American commission in the late 1980s for the ballet Sundown Dances which was premièred at the Kennedy Center in May 1991.

Many parallels can be drawn between the careers, as well as the music, of Dutilleux and Ohana, despite the disparity in the quantity of their respective outputs. Ohana was extraordinarily prolific, preferring to move on to a new work rather than spend too long on correction and revision. Dutilleux, on the other hand, is well-known for the long gestation that many of his works have required, as well as for his fastidiousness in correction and revision. During the 1950 s both continued to write incidental music, an important vehicle for stylistic experimentation,

\footnotetext{
"Henri Dutilleux in Le Monde de la Musique, Cahier no.2 'Maurice Ohana, le musicien du soleil' (1994) p.18. Translation by the present author.
}

"The Boston Symphony under Leonard Bernstein gave the first performance of Messiaen's Turangalila-Symphonie in December 1949, with Yvonne Loriod and Ginette Martenot. 
particularly in the case of Ohana who was able to investigate the use of third-tone microintervals prior to incorporating them into his concert works, and both composed a number scores for the ballet. Dutilleux's scores for $L a$ belle and Le loup of 1953 were choreographed by Roland Petit, while Ohana collaborated with Maurice Béjart on Les répresentations de Tanit (1951) and Prométhée (1956). (Ohana's third ballet of the 1950s, Etudes chorégraphiques, was a joint commission from the Norddeutscher Rundfunk and the Hamburg Ballet but was later revised for Les percussions de Strasbourg with choreography by Manuel Parrès.) Both provided scores for Jean-Louis Barrault's theatre company; Dutilleux's just before they left the Comedie française (Jolivet conducted), Ohana's some years later after the appointment of Boulez, who conducted Soirée des proverbes in January 1954 at the Theâtre Marigny. Both composed string quartets for the Quatour Parrenin; Ohana's Cinq séquences was premièred by them in November 1964, Dutilleux's Ainsi la mit in January 1977. Both received commissions from Rostropovitch: Dutilleux for Tout un monde lointain... (1967-70), Trois strophes sur le nom de Sacher (1976-82) and Timbres, espace, mouvement (1976-78/1990); Ohana for Syrtes (1970) and the Second Cello Concerto 'In dark and blue' (1990), premièred in May 1991 with Seiji Osawa conducting. By the late 1950 s Dutilleux and Ohana were attracting the attention of musical commentators, their music being discussed by Claude Rostand, Jean Roy, Bernard Gavoty, Daniel-Lesur, Antoine Goléa, Claude Chameray, Frederick Goldbeck and Rollo Myers, and numerous interviews were published. It is significant, however, that neither Dutilleux nor Ohana was discussed in Hodeir's influential study of 20th-century music, Since Debussy, which has much in common with the more Boulezian aesthetic. More recently, both have been the subject of studies by Francis Bayer (a composer known in France who was a student of Dutilleux and Ohana), as well as many articles and interviews. During the 1980s, two special editions of the Revue musicale were devoted to Ohana" and two monographs discussing the music of Dutilleux were published in France." Further studies of their work have been published in English during the 1990s."

One of the most significant parallels between Dutilleux and Ohana was their respective exclu-

\footnotetext{
"Double numéro 351-353 'Maurice Ohana Essais études et documents' (1982) and a Triple numéro 391-393 'Maurice Ohana miroirs de l'oeuvre' (1986).
}

Daniel Humbert: Henri Dutilleux l'Oenure et le style musical (Paris 1985), Pierrette Mari: Henri Dutileux (Paris, 1988). sion from representation at the Domaine musical. Their resultant estrangement from Boulez affected the promotion of their music in Britain, particularly during the $1960 \mathrm{~s}$ and 1970 s. Although Dutilleux now describes his relationship with 'Monsieur Boulez' as 'much more cordial,, it is interesting to note that no commission was forthcoming when the Ensemble Intercontemporain was founded in 1977. When Boulez finally offered a commission in the early 1990s the project was eventually abandoned as Dutilleux did not wish to write for a soloist from the Ensemble Intercontemporain." Apart from the Jean-Louis Barrault theatre company commission in 1954, Ohana received no commission from Boulez. Neither in the 1960 s and 1970 s, nor in more recent years, has Boulez chosen to conduct the music of Dutilleux or Ohana. Likewise, Boulez does not conduct the music of Lutoslawski, perhaps as a result of disagreements at the time of the première of the 'Direct' movement of the Second Symphony in 1966. (Lutoslawski's Second Symphony received its complete première a year later with the composer conducting).

The dangers of promoting too narrow a view of contemporary music were recognized in France sooner than in Britain. The composer and conductor Marius Constant, who co-founded the specialist music programme France-Musique at French radio in 1954, the same year Boulez founded the Concerts du Domaine musical, considered it unhealthy to allow a single musical aesthetic to be viewed as entirely representative. Constant another stylistically independent figure - later wrote: 'In the 1960 s, not to be serialist was like having some shameful disease. ${ }^{29}$ In 1963 he founded the Ensemble Ars nova, specifically to counteract the influence of the Domaine musical. With Constant as their artistic and musical director, they became the official new group at French radio, reviving its tradition of pluralism in music broadcasting. They broadcast a wide spectrum of new music, including the non-serial as well as the serial, and provided an important platform for disseminating the music of composers of the 'other' French avant-garde which would otherwise have found difficulty in reaching a

\footnotetext{
Monograph on Dutilleux by Caroline Potter (London, 1997). Various articles on Ohana by Caroline Rae, who is also the author of a monograph on Ohana (London, 2000).

$r$ Dutilleux in conversation with the author in Paris, March 1998.

'Caroline Potter: op.cit., p.22

'Portrait - Marius Constant', Salabert-Actuel no. 5 (Paris, 1987) p.11-12. Translation by the present author
} 


\section{BBC Broadcasts of Music by Selected French Composers 1945-69}

(all networks)

Includes broadcasts of live concerts, recorded concerts, commercial recordings and repeat broadcasts

\begin{tabular}{|l|c|c|c|c|c|}
\hline & $1945-49$ & $1950-54$ & $1955-59$ & $1960-64$ & $1965-69$ \\
\hline Boule $z$ & 0 & 0 & 2 & 20 & 66 \\
\hline Constant & 0 & 3 & 1 & 4 & 5 \\
\hline Dutilleux & 4 & 1 & 6 & 2 & 6 \\
\hline Jolivet & 0 & 14 & 16 & 6 & 9 \\
\hline Daniel-Lesur & 4 & 2 & 2 & 0 & 1 \\
\hline Messiaen & 4 & 25 & 16 & 86 & 231 \\
\hline Ohana & $(1)$ & 0 & 4 & 5 & 2 \\
\hline
\end{tabular}

(brackets indicate appearance as a performer)

wider audience. During the 1960s, Ars nova premièred a number of Ohana's most innovative works, including Signes (1965) for flute, zithers, piano and percussion, and the chamber opera Syllabaire pour Phèdre (1967). Constant also conducted the première of Ohana's First Cello Concerto, Anneau du Tamarit with Alain Meunier and the Orchestre des Concerts Colonne in December 1977.

In Britain the broadcasting climate during the 1960 s and 1970s was rather different. With Sir William Glock at the BBC as both Controller of Music and Director of the Proms, contemporary music was certainly promoted - but according to a supposed canon which posterity has shown not to be entirely representative. In 1972 Francis Routh drew attention to the dangers of presenting too narrow a view of contemporary music. Although he was considering the problem from the perspective of contemporary British music, his ungloved criticisms of the BBC monopoly in 'Cause for Concern' could apply equally to the European composers, similarly excluded at the time:

The BBC Music Department has not kept pace with the enormously increased range of contemporary music.... an extreme instance of this limitation occurred in the 1960s when the newly appointed Head of Music, William Glock, exercised the power vested in his position to promote particular composers of the serialist and avant-garde school. Those who were not of this persuasion were disregarded, and their works were not broadcast... A trend was thus set which was undesirable because it was lopsided and unrepresentative."

Although Glock was frequently critical of what he considered a middle-of-the-road approach to programming at the BBC Music Department prior to his appointment, examination of the

'F. Routh: 'Cause for Concern', Contemporary British Music (London, 1972), p.372. broadcasting archives of the period reveal that new music, including that of the French, was not ignored under the direction of his predecessors." From 1945 to 1949 there were 12 separate broadcasts to works by Dutilleux, Messiaen and Daniel-Lesur on the Third Programme and Home Service, in addition to 14 broadcasts of six works by Lili Boulanger during the period 1945 to 1951 . (There were also two broadcasts of a work by Nadia Boulanger). Still relatively few if compared with broadcasts of music by arguably more popular French composers; there were approximately 500 broadcasts of works by Poulenc and more than 2000 of works by Ravel over the same period. Even prior to Glock's appointment, broadcasts of Messiaen during the 1950s totalled 41, no doubt largely as a result of the influence and enthusiasm of Felix Aprahamian, who was instrumental in first introducing Messiaen's music to England during the 1930s." During the 1950s, broadcasts of music by other living French composers included 30 works by Jolivet, seven by Dutilleux, four of Ohana, Constant and Daniel-Lesur and two of Boulez. There were even two broadcasts of Symphomie pour un homme seul by Schaeffer and Henri as well as at least one of an unspecified work by Giacinto Scelsi. (See table above.)

The Dutilleux broadcasts of the 1950s included the British première of the First Symphony in 1955 (only four years after its French première by the French radio orchestra under Désormière), as well as the symphonic fragments from the ballet Le loup. Those of Ohana's included the Llanto por Ignacio Sanchez Mejias and Cantigas, both of which had only recently been premièred in

"The files of composers, performers and broadcast schedules 1945-69 at the BBC Written Archive Centre, Caversham, Reading.

"Bien Cher Félix: Letters from Olivier Messiaen and Yvorme Loriod to Felix Aprahamian ed. \& tr. Nigel Simeone (Cambridge, 1998). 
Paris and Hamburg, respectively. Similarly perceptive programming included the first British broadcasts in 1951 of Messiaen's Quatuor pour la fin du temps and Cinq rechants, as well as two broadcasts of the British première of the Turangalila-Symphonie in 1953." The two Boulez broadcasts were in March 1957 and represented the first British broadcasts of Structures $I$ and Marteau sans maitre, fresh from the Domaine musical. It is almost certain that Glock had an input into this promotion, given that the same year Boulez appeared in two concerts for the ICA while Glock was chairman, the programme including Webern, Stockhausen and Nono." It is true that Proms programmes of the 1950 s promoted little contemporary music compared with those of the following decade, although there were Prom premières of new works by Panufnik (another casualty of the 1960s and 1970s) as well as by Jolivet, Milhaud, Martinü, Ibert, Gerhard and Petrassi.

Following Glock's appointment as Controller of Music in 1959, the influence of his collaboration with Boulez is reflected in the virtual explosion of coverage that the music of Messiaen and Boulez received, both on the airwaves and in the concert-hall. While such championing is certainly only to be praised, the effect of absorbing the Boulezian aesthetic, which was continued well after Glock's retirement in the $1970 \mathrm{~s}$, resulted in the comparative neglect of the music of Dutilleux, Ohana and others. Although there were several broadcasts of their music during the 1960s, including the première of Ohana's guitar concerto Trois graphiques in 1961, with the LSO and Narciso Yepes under Anthony Bernard, and a broadcast recording of Dutilleux's Second Symphony in 1965 , the tendency to repeat broadcasts of their earlier works would not have aided awareness of their musical style as it developed and matured. The broadcasts of music by Boulez and Messiaen during the 1960 s were not only far more numerous but included repeat broadcasts of their most recent works. That the majority of Dutilleux's broadcasts were restricted to the Sonatine for flute and piano, the Piano Sonata, the Sarabande et cortège for bassoon and piano and Le loup would only have aided the impression that he was rather more conservative in his

Messiaen first visited London in 1938 to perform La Nativité de Seigneur at St Alban the Martyr, Holborn. He visited again in December 1945 when he and Yvonne Loriod performed $V$ isions de l'Amen for an invited audience at the home of Felix Aprahamian. (N. Simeone op.cit.).

'W. Glock: 'With Boulez at the BBC', Pierre Boulez A Symposium (1986) p.233. compositional approach than was actually the case. Dutilleux has long discouraged the performance of these works precisely because they are not indicative of the mature style which crystallized in Métaboles of 1964.

The influence of Glock and Boulez naturally extended to the Proms. Boulez was first represented on 29 August 1961 with a performance by Heather Harper and the New Music Ensemble under John Carewe of the second of the Improvisations sur Mallarmé 'Une dentelle s'abolit'.3. The same season also included the Proms première of Le Marteau sans maitre. Messiaen was first heard at the Proms on 24 August 1962 with Cinq rechants and Oiseaux exotiques, the latter performed by the BBCSO under John Carewe with Aloys Kontarsky as the soloist."

The music of Dutilleux was not heard at the Proms until 1989, 28 years after his younger French contemporary Boulez had first been represented. On 25 August that year Métaboles was performed by the Orchestre de Radio France under Marek Janowski, 24 years after the work had been premièred by the Cleveland Orchestra and Georges Szell (January 1965). That Dutilleux had been a featured composer at the Huddersfield and Aldeburgh festivals during the 1980 s had certainly increased awareness of his music, although long overdue. During the 1990 s, the Proms administrators worked hard to rectify the omission from their programmes of one of France's leading living composers: $M \gamma$ stère de l'instant and the Second Symphony were performed in 1991; Tout un monde lointain in 1992; the violin concerto L'Arbre des songes and the string quartet Ainsi la mit in 1996; and The Shadows of Time in 1998 less than a year after its world première in Boston under Seiji Ozawa. Although pluralism may now be the middle name of contemporary music editors and Proms programmers at the $\mathrm{BBC}$, for which they should be congratulated, neither Constant nor Ohana have as yet been represented. During the 1980 s British performances and broadcasts of Ohana's music in other contexts have, however, increased. His music continues to be regularly performed in France and since his death in 1992 new recordings continue to be released and an international prize, 'le Prix Maurice Ohana', awarded biennially to composers and pianists, has been established in his memory. As Constant is now in his middle seventies and sadly Ohana is no longer with us, the music of these two

The work had already received its UK premiére at Dartington two years before.

The Kontarsky brothers first performed at the Proms 1960. 
composers is perhaps less newsworthy for British audiences than that of their younger contemporaries, among whom Tristan Murail, Gérard Grisey, Maurice Delaistier and François Bayle are not entirely unfamiliar, although the music of Alain Louvier, Pascal Dusapin, Hugues Dufourt,
Philippe Manoury, Edith Canat de Chizy, Felix Ibarrondo and others still largely remains to be discovered. One hopes that Dutilleux, now in his eighty-fifth year, will continue, health permitting, to compose for many years.

Friday 30 June $\bullet 8 \mathrm{pm}$ (World Première) Sunday 2 July $\bullet 3 \mathrm{pm}$ BROCHURE 01242237377 BOX OFFICE 01242227979 www.cheltenhamfestivals.co.uk

\section{MB UXTON festival}

Tuesday 18 July $\bullet 7.30 \mathrm{pm}$ Friday 21 July $\bullet 7.30 \mathrm{pm}$ INFORMATION 0129870395 BOX OFFICE 0129872190 www.buxtonfestival.co.uk 